\title{
Maternal supplementation with cobalt sources, folic acid, and rumen- protected methionine and its effects on molecular and functional correlates of the immune system in neonatal Holstein calves
}

\author{
M. G. Lopes, ${ }^{1,2} \odot$ A. S. Alharthi, ${ }^{3}$ V. Lopreiato, ${ }^{4} \odot$ E. Abdel-Hamied, ${ }^{5}$ Y. Liang, ${ }^{1} \odot$ D. N. Coleman, ${ }^{1} \odot$ H. Dai, ${ }^{6}$ \\ M. N. Corrêa, ${ }^{2}$ M. T. Socha, ${ }^{7}$ (i) M. A. Ballou, ${ }^{8}$ (D) E. Trevisi, ${ }^{4}$ (i) and J. J. Loor ${ }^{1 *}$ (i) \\ ${ }^{1}$ Department of Animal Sciences and Division of Nutritional Sciences, University of Illinois, Urbana 61801 \\ ${ }^{2}$ NUPEEC (Núcleo de Pesquisa, Ensino e Extensão em Pecuária), Departamento de Clínicas Veterinária, \\ Programa de Pós-Graduação em Biotecnologia, Universidade Federal de Pelotas, 96010-610, Pelotas, RS, Brazil \\ ${ }^{3}$ Department of Animal Production, College of Food and Agriculture Sciences, King Saud University, Riyadh 11451, Saudi Arabia \\ ${ }^{4}$ Department of Animal Sciences, Food and Nutrition, Faculty of Agriculture, Food and Environmental Science, \\ Università Cattolica del Sacro Cuore, 29122 Piacenza, Italy \\ ${ }^{5}$ Department of Animal Medicine, Faculty of Veterinary Medicine, Beni-Suef University, Beni-Suef 62511, Egypt \\ ${ }^{6}$ College of Animal Science and Veterinary Medicine, Henan Agricultural University, Zhengzhou 450002, China \\ ${ }^{7}$ Zinpro Corporation, Eden Prairie, MN 55344 \\ ${ }^{8}$ Department of Veterinary Sciences, Texas Tech University, Lubbock 79409
}

\section{ABSTRACT}

Calves born to multiparous Holstein cows fed during the last $30 \mathrm{~d}$ of pregnancy 2 different cobalt sources [cobalt glucoheptonate (CoPro) or cobalt pectin (CoPectin)], folic acid (FOA), and rumenprotected methionine (RPM) were used to study neonatal immune responses after ex vivo lipopolysaccharide (LPS) challenge. Groups were $(\mathrm{n}=12$ calves/ group) CoPro, FOA+CoPro, FOA+CoPectin, and FOA + CoPectin+RPM. Calves were weighed at birth and blood collected at birth (before colostrum), $21 \mathrm{~d}$ of age, and $42 \mathrm{~d}$ of age (at weaning). Growth performance was recorded once a week during the first 6 wk of age. Energy metabolism, inflammation, and antioxidant status were assessed at birth through various plasma biomarkers. Whole blood was challenged with $3 \mu \mathrm{g} / \mathrm{mL}$ of LPS or used for phagocytosis and oxidative burst assays. Target genes evaluated by real-time quantitative PCR in whole blood samples were associated with immune response, antioxidant function, and 1-carbon metabolism. The response in mRNA abundance in LPS challenged versus nonchallenged samples was assessed via $\Delta=$ LPS challenged - LPS nonchallenged samples. Phagocytosis capacity and oxidative burst activity were measured in neutrophils and monocytes, with data reported as ratio (percentage) of CD14 to CH138A-positive cells. Data including all time points were subjected to ANOVA using PROC MIXED in SAS 9.4 (SAS Institute Inc.), with Treatment, Sex,

Received September 18, 2020.

Accepted March 30, 2021

*Corresponding author: jloor@illinois.edu
Age, and Treatment $\times$ Age as fixed effects. A 1-way ANOVA was used to determine differences at birth, with Treatment and Sex as fixed effects. Calf birth body weight and other growth parameters did not differ between groups. At birth, plasma haptoglobin concentration was lower in FOA+CoPro compared with CoPro calves. We detected no effect for other plasma biomarkers or immune function due to maternal treatments at birth. Compared with CoPro, in response to LPS challenge, whole blood from FOA+CoPectin and $\mathrm{FOA}+\mathrm{CoPectin}+\mathrm{RPM}$ calves had greater mRNA abundance of intercellular adhesion molecule 1 (ICAM1). No effect for other genes was detectable. Regardless of maternal treatments, sex-specific responses were observed due to greater plasma concentrations of haptoglobin, paraoxonase, total reactive oxygen metabolites, nitrite, and $\beta$-carotene in female versus male calves at birth. In contrast, whole blood from male calves had greater mRNA abundance of IRAK1, CADM1, and ITGAM in response to LPS challenge at birth. The longitudinal analysis of $\mathrm{d} 0,21$, and 42 data revealed greater bactericidal permeability-increasing protein $(B P I)$ mRNA abundance in whole blood from FOA+CoPectin versus FOA+CoPro calves, coupled with greater abundance in FOA+CoPro compared with CoPro calves. Regardless of maternal treatments, most genes related to cytokines and cytokine receptors (IL1B, IL10, TNF, IRAK1, CXCR1), toll-like receptor pathway (TLR4, NFKB1), adhesion and migration (ICAM1, ITGAM), antimicrobial function $(M P O)$, and antioxidant function (GPX1) were downregulated over time. Phagocytosis capacity and oxidative burst activity in both neutrophils and monocytes did not differ due to maternal treatment. Regardless of maternal treatments, we observed an 
increase in the percentage of neutrophils capable of phagocytosis and oxidative burst activity over time. Overall, these preliminary assessments suggested that maternal supplementation with FOA and Co combined with RPM had effects on a few plasma biomarkers of inflammation at birth and molecular responses associated with inflammatory mechanisms during the neonatal period.

Key words: methyl donors, neonatal immunity, nutritional programming, vitamin $\mathrm{B}_{12}$

\section{INTRODUCTION}

Cellular functions of the neonatal immune system require an initial period of maturation through exposure to new antigens, with some data suggesting that nutritional status during late stages of fetal life also is critical (Hulbert and Moisá, 2016; Jacometo et al., 2018; Alharthi et al., 2019b). The role of methyl donors and 1-carbon metabolism in dairy cattle has received substantial attention over the past few decades (Girard et al., 1995; Girard and Matte, 2005; Zhou et al., 2016b). Benefits of greater methyl donor supply to both dams and offspring in terms of production and health parameters are clear (Zenobi et al., 2018; Coleman et al., 2020). For instance, several studies with dietary methyl donors (e.g., methionine, choline, and folic acid) in peripartal dairy cows have confirmed benefits in performance, health, and immune function (Graulet et al., 2007; Osorio et al., 2013a; Vailati-Riboni et al., 2017b; Arshad et al., 2020). Many of these benefits were also linked to positive responses on aspects of energy metabolism, inflammation, antioxidant status, and birth BW in the offspring (Jacometo et al., 2016; Alharthi et al., 2019a; Duplessis and Girard, 2019), underscoring that adequate supply of methyl donors during later stages of fetal life is an important determinant of immunocompetence and growth in the neonatal calf (Alharthi et al., 2018, 2019b; Zenobi et al., 2018).

Metabolism of the essential nutrients folic acid (FOA) and methionine (Met) is key for production of homocysteine and S-adenosylmethionine, the main donor of methyl groups (Preynat et al., 2010). The FOA and Met cycles are linked through the activity of methionine synthase (MTR), which has an absolute requirement for vitamin $\mathrm{B}_{12}$ (Xue and Snoswell, 1985a; Lucock, 2000). This water-soluble vitamin is synthesized by the ruminal microbiome from the trace mineral cobalt in the diet (Stemme et al., 2008). Because newborn calves do not have a functional rumen, they depend on FOA and $\mathrm{B}_{12}$ acquired in the uterine environment and through colostrum and milk intake (Duplessis and Girard, 2019). From a physiological point of view, increased supply of FOA and cobalt, the latter by enhancing $\mathrm{B}_{12}$ ruminal synthesis, could lead to greater endogenous Met synthesis (i.e., remethylation; Xue and Snoswell, 1985a,b). Although isolated effects of maternal supplementation with methyl donors during early postnatal life have already been demonstrated (Jacometo et al., 2016, 2017, 2018; Abdelmegeid et al., 2017; Alharthi et al., 2018, 2019a,b), it remains to be determined whether increased supply of FOA and $\mathrm{B}_{12}$, through increased cobalt supply, alone or combined with Met, generate similar effects in neonatal innate immune responses.

Our hypothesis was that additional sources of 1-carbon units from an increase in the supply of dietary methyl donors for the dam enhance offspring innate immune function during early postnatal life. To test this hypothesis for the first time, calves born to multiparous Holstein cows fed during the last $30 \mathrm{~d}$ of pregnancy an experimental FOA, 1 of 2 cobalt sources [cobalt glucoheptonate (CoPro) or cobalt pectin (CoPectin)] and rumen-protected methionine (RPM) were retrospectively selected based on completeness of performance data from birth to $6 \mathrm{wk}$ of age, whole blood mRNA abundance of target genes associated with immune response, antioxidant function, and 1-carbon metabolism after ex vivo whole blood LPS challenge, and peripheral blood neutrophil and monocyte function after ex vivo enteropathogenic bacteria challenge.

\section{MATERIALS AND METHODS}

\section{Experimental Design}

All procedures were conducted with the approval of the University of Illinois Institutional Animal Care and Use Committee (protocol no. 17168). The cow study was performed as a randomized complete blocked design with 72 Holstein cows blocked according to parity, previous lactation milk yield, and expected day of parturition. A power calculation was performed using an online resource (kindly made available online by Dr. Rollin Brant, University of British Columbia, Vancouver, CA) comparing a mean to a known value. We defined the outcomes of performance and blood of our data set and its variability. The relevant values for $\mu 0$ (known value), $\mu 1$ (mean of the population to be sampled), $\sigma$ (SD of the sampled population), and sample size were included in the model with $\alpha=0.05$ (type I error rate). Analyses indicated a power $>0.80$. Out of a total of $19,17,18$, and 18 calves born to cows in the respective treatment groups (described subsequently), some could not be sampled or could not complete the entire study due to not meeting the selection criteria, illness, or missed sampling due to human error. Ultimately, the number of calves $(n=12 /$ group $)$ 
used to perform all analyses described in the present study was greater than previously reported in studies dealing with the association between maternal nutrition or stress in the prepartal period and neonatal calf growth and development (Jacometo et al., 2015, 2016; Ling et al., 2018).

Despite the removal of calves due to issues previously outlined, we believe that retrospective selection of calves with a complete set of performance, molecular, and functional data as the sole criteria strengthens the physiological relevance of the data reported here. According to our hypothesis, supplementation with FOA and cobalt can increase endogenous Met synthesis via MTR activity, as well as combined Met supplementation can generate additional S-adenosylmethionine. Thus, we performed the trial with an approach to investigate 2 cobalt sources coupled with an experimental FOA source alone or combined with RPM. In addition to evaluating 2 chemically distinct cobalt sources, dividing cows into CoPro, FOA+CoPro, FOA+CoPectin, and FOA+CoPectin+RPM groups allowed us to evaluate the additive effect of FOA or Met (i.e., FOA+CoPectin vs. FOA+CoPro, $\mathrm{FOA}+\mathrm{CoPro}$ vs. CoPro, and $\mathrm{FOA}+\mathrm{CoPectin}+\mathrm{RPM}$ vs. FOA+CoPectin). Cows in each FOA group received $50 \mathrm{~g}$ of FOA (experimental ruminally available folic acid source). The Co treatments delivered $1 \mathrm{mg}$ of $\mathrm{Co} / \mathrm{kg}$ of DM (CoPro or CoPectin, Zinpro Corp.). The RPM (Smartamine M, Adisseo NA) was fed at $0.09 \%$ of DM to achieve a ratio of 2.8:1 Lys:Met in the MP. During the close-up period, cows were housed in a sand-bedded freestall barn and fed a TMR daily (0600 h) with ad libitum access to the same basal diet (1.37 $\mathrm{Mcal} / \mathrm{kg}$ of $\mathrm{DM}, 14.5 \% \mathrm{CP}$ ), using an individual gate feeding system (American Calan). Treatments were top-dressed from -30 to $30 \mathrm{~d}$ before or after parturition. Diet ingredient and nutrient composition during the close-up period are available in Supplemental Table S1 (https://data.mendeley.com/datasets/77w69zsbp6/ $2)$. When the expected calving date approached, cows were moved to individual pens bedded with straw.

After calving, total colostrum volume was recorded, and total IgG concentration was immediately estimated at room temperature $\left(22^{\circ} \mathrm{C}\right)$ based on specific gravity, with a colostrometer (Bovine Colostrometer, catalog no. C10978N, Nasco). Calves [n = 12/group: CoPro ( 7 male, 5 female), FOA+CoPro (6 male, 6 female), FOA+CoPectin (5 male, 7 female), and FOA+CoPectin+RPM (7 male, 5 female)] were used in the study if all the following criteria were fulfilled: (1) single calf, (2) calving difficulty score $\leq 3$ (5-point scale), (3) colostrum quality, assessed through a colostrometer, of total $\mathrm{IgG} \geq 60 \mathrm{mg} / \mathrm{mL}$, (4) dam produced at least 3.8 L of good-quality first colostrum, and (5) calf birth BW $\geq 40 \mathrm{~kg}$ (Jacometo et al., 2016).

Immediately after birth, calves were weighed using a digital scale and removed from their dams. Cows were milked in the parlor, where the volume of colostrum was recorded, and calves were fed with first-milking fresh colostrum from their respective dam using nipple bottles within $6 \mathrm{~h}$ after birth. All calves received 3.8 $\mathrm{L}$ of first colostrum; if voluntary colostrum intake did not reach $3.8 \mathrm{~L}$, calves were force-fed via esophageal tube to reach the required amount of colostrum. Calves were housed in individual outdoor hutches bedded with straw and fed twice daily (0600 h and $1800 \mathrm{~h}$ ) with milk replacer (Advance Excelerate, Milk Specialties; 28.5\% CP, $15 \%$ fat) until 35 d of age. From 36 d of age until weaning (42 d of age), calves were switched to oncedaily feeding at $0600 \mathrm{~h}$. In detail, calves received 4.54 $\mathrm{kg} / \mathrm{d}$ of milk replacer $(0.59 \mathrm{~kg}$ of milk replacer in 3.95 L of water) from 1 to $10 \mathrm{~d}$ of age, $5.90 \mathrm{~kg} / \mathrm{d}(0.77 \mathrm{~kg}$ of milk replacer in $5.13 \mathrm{~L}$ of water) from 11 to $20 \mathrm{~d}$ of age, $7.26 \mathrm{~kg} / \mathrm{d}(0.94 \mathrm{~kg}$ of milk replacer in $6.32 \mathrm{~L}$ of water $)$ from 21 to $35 \mathrm{~d}$ of age, and $3.63 \mathrm{~kg} / \mathrm{d}(0.47 \mathrm{~kg}$ of milk replacer in $3.16 \mathrm{~L}$ of water) in a single feeding from 36 to $42 \mathrm{~d}$ of age, and had ad libitum access to a starter grain mix (Ampli-Calf Starter 20, 19.9\% CP and 13.5\% NDF, Purina Animal Nutrition). Growth performance including BW, body length, hip height, wither height, and hip width was recorded for each calf once a week during the first 6 wk of age. Health checks, including body temperature, respiratory rate, and fecal score (Osorio et al., 2012), were recorded weekly. All calves retained in the study remained clinically healthy, and sick animals were excluded to avoid bias in our data due to an exogenous challenge of the immune system.

\section{Energy Metabolism, Inflammation, and Antioxidant Status at Birth}

Energy metabolism, inflammation, and antioxidant status were assessed only in blood samples at birth and before colostrum feeding, through several plasma biomarkers. In brief, glucose $(\mathrm{mmol} / \mathrm{L})$ and albumin $(\mathrm{g} / \mathrm{L})$ were analyzed using the IL Test (catalog nos. 0018250840, and 0018250040, respectively) purchased from Instrumentation Laboratory Spa in the ILAB 600 clinical auto-analyzer (Instrumentation Laboratory). Fatty acids (mmol/L) and BHBA (mmol/L) were measured using kits from Wako Chemicals GmbH and Randox Laboratories Ltd., respectively (Bionaz et al., 2007; Trevisi et al., 2012). Haptoglobin (g/L) and ceruloplasmin $(\mu \mathrm{mol} / \mathrm{L})$ were analyzed as described by Bertoni et al. (2008). Myeloperoxidase (U/L) and paraoxonase $(\mathrm{U} / \mathrm{mL})$ were determined as previously de- 
scribed by Bradley et al. (1982) and Bionaz et al. (2007), respectively. Total reactive oxygen metabolites ( $\mathrm{mg}$ of $\mathrm{H}_{2} \mathrm{O}_{2} / 100 \mathrm{~mL}$ ) was determined with a commercial kit (Diacron International s.r.l.). Ferric reducing ability of plasma $(\mu \mathrm{mol} / \mathrm{L})$ was measured using the colorimetric method of Benzie and Strain (1996). Plasma nitric oxide metabolites $(\mu \mathrm{mol} / \mathrm{L})$, nitrite $(\mu \mathrm{mol} / \mathrm{L})$, and nitrate $(\mu \mathrm{mol} / \mathrm{L})$ were measured using the Griess test according to Gilliam et al. (1993) and Bouchard et al. (1999). Retinol $(\mu \mathrm{g} / \mathrm{mL}), \alpha$-tocopherol $(\mu \mathrm{g} / \mathrm{mL})$, and $\beta$-carotene $(\mathrm{mg} / 100 \mathrm{~mL})$ were analyzed as described by Trevisi et al. (2013). Zinc $(\mu \mathrm{mol} / \mathrm{L})$ was determined with a commercial kit (Wako Chemicals GmbH; Bionaz et al., 2007).

\section{Whole-Blood Ex Vivo LPS Challenge}

The ex vivo LPS challenge was performed as described in our recent work with whole blood in calves (Lopes et al., 2021). Calf whole blood samples were collected from the jugular vein using 20-gauge needles (BD Vacutainer, Becton Dickinson and Company) at 0 (at birth and before colostrum feeding), 21, and $42 \mathrm{~d}$ of age (at weaning). Samples were collected into evacuated tubes containing lithium heparin as an anticoagulant (BD Vacutainer, Becton Dickinson and Company) and immediately transported to the laboratory in a thermo-insulated container with water $\left(38^{\circ} \mathrm{C}\right)$. Whole blood samples were challenged with $3 \mu \mathrm{g} / \mathrm{mL}$ of LPS (Escherichia coli O111:B4, Sigma-Aldrich) no later than 10 min after sampling. In brief, 2 aliquots of $980 \mu \mathrm{L}$ of whole blood were stimulated in duplicate with $20 \mu \mathrm{L}$ of Dulbecco's modified Eagle medium (nonchallenged control samples) or with $20 \mu \mathrm{L}$ of LPS solution (challenged samples). Aliquots were incubated in a water bath for $3.5 \mathrm{~h}$ at $38^{\circ} \mathrm{C}$ with a horizontal shaking speed of 30 times/min (Jahan et al., 2015; Vailati-Riboni et al., 2017b). Environmental contamination with exogenous endotoxin was prevented by using certified endotoxinfree materials.

\section{Whole-Blood mRNA Extraction, cDNA Synthesis, and Quantitative Real-Time PCR}

After LPS challenge, whole blood mRNA extraction was performed using Trizol protocol (TRI Reagent BD, Sigma-Aldrich) as recommended by the manufacturer. Possible residue from genomic DNA was removed by purification with on-column DNase digestion (RNaseFree DNase Set, Qiagen), and RNA concentration was measured using the NanoDrop ND-1000 (NanoDrop Technologies). All samples had an RNA integrity score greater than 8.0 according to the AATI Fragment Analyzer (Agilent Technologies).
Target genes evaluated encode proteins associated with immune response, antioxidant function, and 1-carbon metabolism. Detailed information can be found in the Supplemental Table S2 (https://data.mendeley. com/datasets/77w69zsbp6/2) and in our previous studies with cows and calves (Abdelmegeid et al., 2017; Jacometo et al., 2018; Zhou et al., 2018; Lopes et al., 2021). The cDNA synthesis was performed following the same protocol recently described in our study with calf whole blood (Lopes et al., 2021). Quantitative real-time PCR was performed in a MicroAmp Optical 384-Well Reaction Plate (Applied Biosystems) using $4 \mu \mathrm{L}$ of diluted 1:4 cDNA and $6 \mu \mathrm{L}$ of SYBR Green mixture (Applied Biosystems) with $0.4 \mu \mathrm{L}$ of $10 \mu \mathrm{M}$ forward and reverse primers, and $0.2 \mu \mathrm{L}$ of nucleasefree water. Each gene was run in triplicate on a single plate with 7-point standard curve plus the negative control. The PCR performance and the information required by the Minimum Information for Publication of Quantitative Real-Time PCR Experiments (MIQE) to ensure quality control can be found in Supplemental Tables S3 and S4 (https://data.mendeley.com/ datasets/77w69zsbp6/2). Data were normalized using the geometric mean of 3 internal control genes: $G A P D H, R P S 9$, and $A C T B$, previously validated by our research group (Liang et al., 2019; Vailati-Riboni et al., 2019; Lopes et al., 2021).

\section{Phagocytosis Capacity and Oxidative Burst Activity}

Simultaneous phagocytosis capacity and oxidative burst activity of peripheral blood neutrophils and monocytes were determined through an ex vivo challenge with enteropathogenic bacteria Escherichia coli (E. coli O118:H8; kindly donated by M. A. Ballou, Texas Tech University, Lubbock), as described by Hulbert et al. (2011) with modifications previously reported by our group (Zhou et al., 2016a; Vailati-Riboni et al., 2017b; Batistel et al., 2018). In brief, whole blood was sampled from jugular vein at 0,21 , and $42 \mathrm{~d}$ of age into evacuated tubes (BD Vacutainer) containing lithium heparin, and placed on ice until the assay was started. First, $200 \mu \mathrm{L}$ of whole blood with $40 \mu \mathrm{L}$ of $100 \mu M$ dihydrorhodamine 123 (Sigma-Aldrich), and $40 \mu \mathrm{L}$ of propidium iodine-labeled bacteria $\left(10^{9} \mathrm{cfu} /\right.$ $\mathrm{mL}$ ) were incubated at $38.5^{\circ} \mathrm{C}$ for $10 \mathrm{~min}$. After red blood cells were lysed with ice-cold MilliQ water (Millipore Corp.), cells were resuspended in PBS solution. Subsequently, neutrophils were stained with CH138A primary anti-bovine granulocyte monoclonal antibody (catalog no. BOV2067, Washington State University) and phycoerythrin-labeled secondary antibody (catalog no. 1020-09S, Southern Biotech), and monocytes were marked with allophycocyanin-labeled anti-CD14 anti- 
body (catalog no. 301808, Biolegend). Finally, cells were resuspended in $400 \mu \mathrm{L}$ of PBS solution for flow cytometry analyses (LSR II, Becton Dickinson). Neutrophils and monocytes were gated based on their side scatter properties in combination with the phycoerythrin and allophycocyanin signal, respectively. Compared with the negative controls, neutrophils and monocytes from E. coli-stimulated samples with greater emissions of propidium iodine were considered positive for phagocytosis. Similarly, compared with negative controls, the $E$. coli-stimulated samples with greater emissions of dihydrorhodamine 123 were considered positive for oxidative burst. Data are reported as ratio (percentage) of CD14 to CH138A-positive cells with phagocytosis and oxidative burst activity.

\section{Statistical Analysis}

The real-time quantitative PCR data were normalized with the geometric mean of the 3 internal control genes and $\log _{2}$ transformed before statistical analysis to obtain a normal distribution.

The response in mRNA abundance in LPS challenged versus nonchallenged samples was analyzed in a similar fashion to a previous study with calves (Ling et al., 2018) using delta change values, $\Delta=$ LPS challenged - LPS nonchallenged samples, as in our previous study (Lopes et al., 2021). Normality of the residuals was tested via Proc Univariate in SAS 9.4 (SAS Institute Inc.). All observations were normally distributed, and observations with absolute value of studentized residual greater than 3 were automatically removed from the analysis. Statistical analysis was performed with SAS 9.4. Data including all time points were subjected to ANOVA using repeated-measures ANOVA with PROC MIXED, including Treatment, Sex, Age, and Treatment $\times$ Age as fixed effects. Data including only the time point at birth were subject to a 1-way ANOVA, with Treatment and Sex as fixed effects. Means were compared using the PDIFF statement in SAS with Tukey test.

\section{RESULTS}

\section{Development, Metabolism, and Immune Function at Birth}

Growth variables did not differ due to maternal treatment at birth nor during the first 6 wk of age $(P>0.05$; Table 1$)$. With the exception of haptoglobin, we detected no difference in energy metabolism, inflammation, or antioxidant status-related biomarkers according to maternal treatments $(P>0.05$; Table $2)$. At birth, haptoglobin was lower in calves born to FOA+CoPro versus CoPro cows $(P<0.05$; Table 2$)$. In addition, at birth, phagocytosis capacity and oxidative burst activity in both neutrophils and monocytes did not differ due to maternal treatment $(P>0.05$; Table 2).

Regardless of maternal treatments, effects of Sex were observed for some inflammation and antioxidant status-related biomarkers, due to greater haptoglobin $(0.37 \pm 0.02$ vs. $0.31 \pm 0.02 \mathrm{~g} / \mathrm{L})$, paraoxonase $(13.19 \pm 1.97$ vs. $6.28 \pm 1.27 \mathrm{U} / \mathrm{mL})$, total reactive

Table 1. Effects of maternal supplementation during the last $30 \mathrm{~d}$ of pregnancy with an experimental folic acid source (FOA), 2 cobalt sources [cobalt glucoheptonate (CoPro) or cobalt pectin (CoPectin)], and rumen-protected methionine (RPM) on calf growth parameters at birth (before colostrum feeding) and during the first 6 wk of age

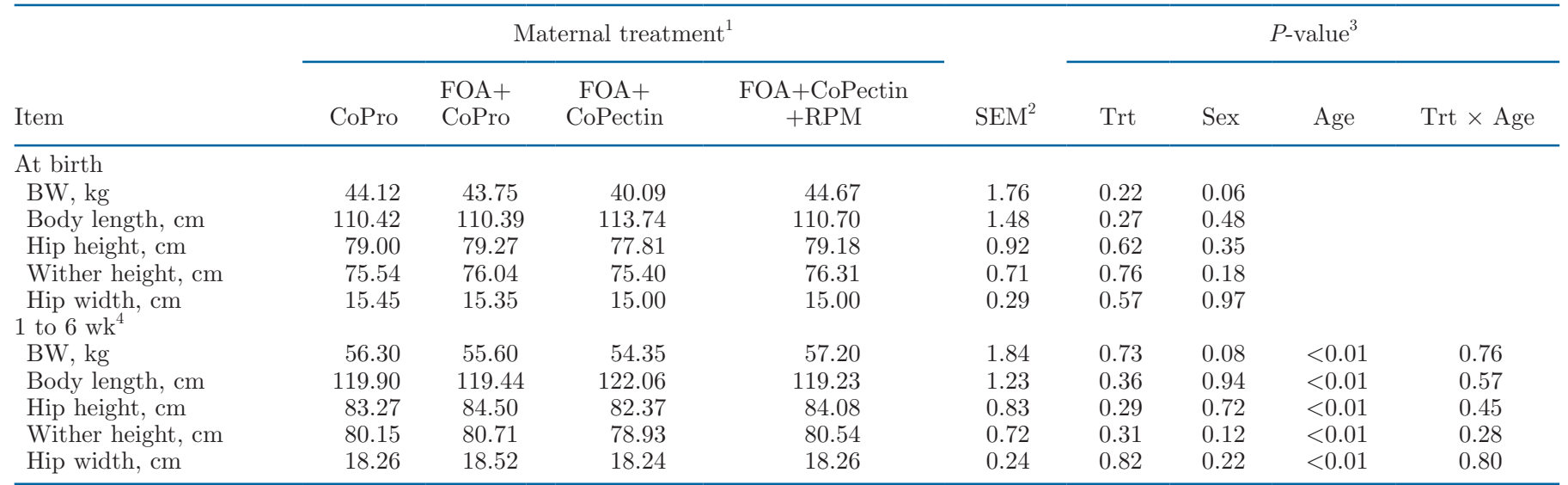

${ }^{1}$ Maternal treatments were CoPro $(\mathrm{n}=12), \mathrm{FOA}+$ CoPro $(\mathrm{n}=12)$, FOA+CoPectin $(\mathrm{n}=12)$, and FOA + CoPectin $+\mathrm{RPM}(\mathrm{n}=12)$.

${ }^{2}$ Greatest SEM.

${ }^{3} \mathrm{Trt}=$ treatment.

${ }^{4} \mathrm{LSM}$ for calf growth parameters including weekly measurements from 1 to 6 wk of age. 
Table 2. Effects of maternal supplementation during the last $30 \mathrm{~d}$ of pregnancy with an experimental folic acid source (FOA), 2 cobalt sources [cobalt glucoheptonate (CoPro) or cobalt pectin (CoPectin)], and rumen-protected methionine (RPM) on plasma concentrations of biomarkers related to energy metabolism, inflammation, and antioxidant status, as well as on immune function of calf leukocytes at birth and before colostrum feeding

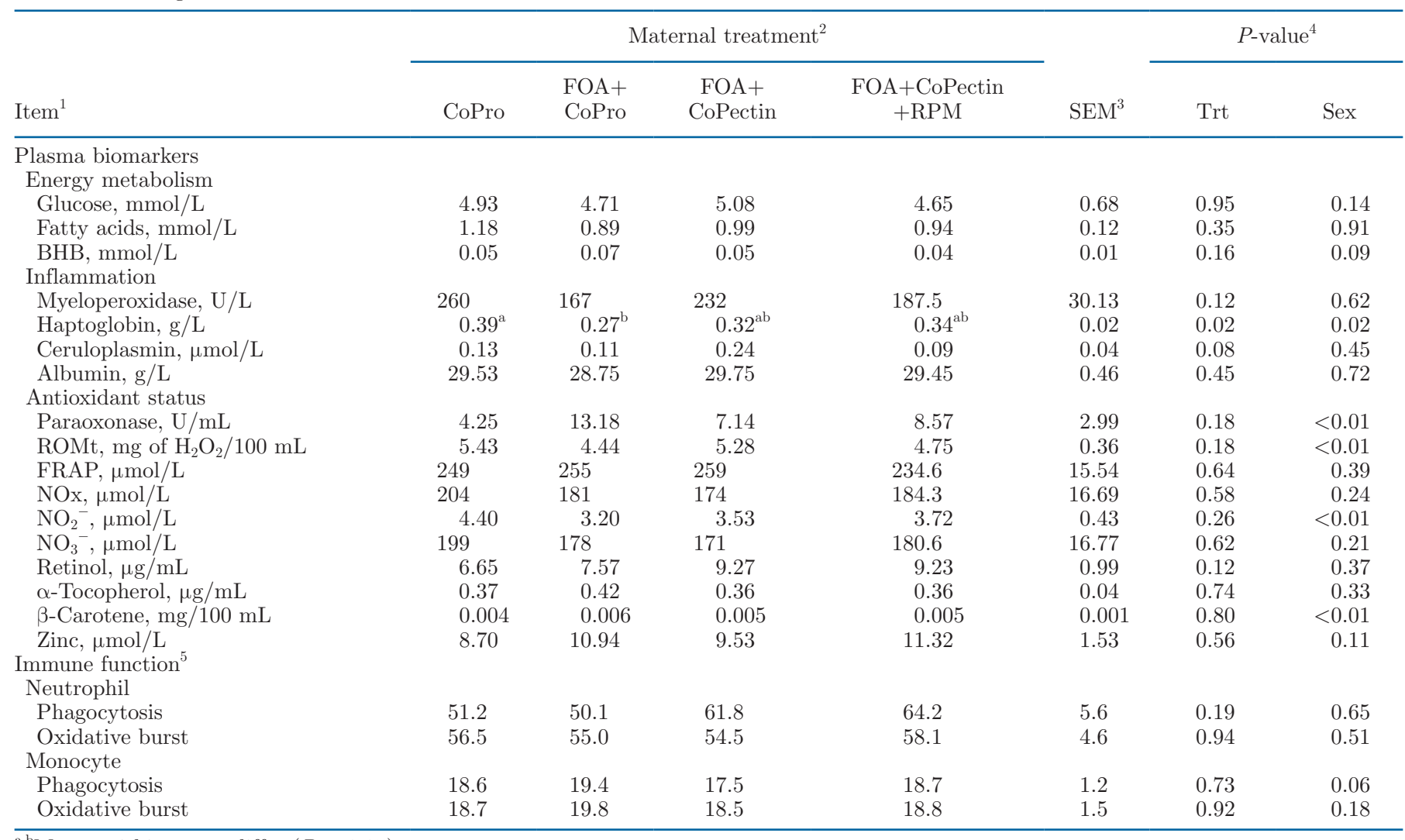

${ }^{\mathrm{a}, \mathrm{b}}$ Means within a row differ $(P \leq 0.05)$.

${ }^{1} \mathrm{NOx}=$ nitric oxide metabolites; $\mathrm{NO}_{2}{ }^{-}=$nitrite; $\mathrm{NO}_{3}{ }^{-}=$nitrate; FRAP $=$ferric reducing ability of plasma; ROMt $=$reactive oxygen metabolites, total.

${ }^{2}$ Maternal treatments were CoPro $(\mathrm{n}=12), \mathrm{FOA}+\operatorname{CoPro}(\mathrm{n}=12), \mathrm{FOA}+\operatorname{CoPectin}(\mathrm{n}=12)$, and FOA $+\operatorname{CoPectin}+\mathrm{RPM}(\mathrm{n}=12)$.

${ }^{3}$ Greatest SEM.

${ }^{4} \mathrm{Trt}=$ treatment

${ }^{5}$ Data reported as ratio (percentage) of CD14 to CH138A-positive cells with phagocytosis and oxidative burst activity.

oxygen metabolites $(5.66 \pm 0.23$ vs. $4.49 \pm 0.20 \mathrm{mg}$ $\left.\mathrm{H}_{2} \mathrm{O}_{2} / 100 \mathrm{~mL}\right)$, nitrite $(4.56 \pm 0.34$ vs. $3.31 \pm 0.29$ $\mu \mathrm{mol} / \mathrm{L})$, and $\beta$-carotene $(0.007 \pm 0.001$ vs. $0.004 \pm$ $0.001 \mathrm{mg} / 100 \mathrm{~mL}$ ) concentrations in female versus male calves at birth $(P<0.05$; Table 2$)$.

\section{Whole-Blood Leukocyte mRNA Abundance}

Cytokine and Cytokine Receptors. At birth, no difference was observed due to maternal treatments for IL1B, IL6, IL10, TNF, IRAK1, and CXCR1 mRNA abundance in whole blood leukocytes after LPS challenge $(P>0.05$; Table 3$)$. In addition, a Sex effect was observed for IRAK1 mRNA abundance due to upregulation in male versus female calves in response to LPS challenge $(\Delta=0.71 \pm 0.37$ vs. $-0.28 \pm 0.31 ; P$ $=0.05$; Table 3 ). Analyzing all time points, regardless of maternal treatments, an Age effect in response to the LPS challenge was detected for most genes measured (Table 4). Over time, we found an Age effect with a decrease in mRNA abundance of $I L 1 B(P<0.01)$, IL10 $(P<0.01)$, TNF $(P<0.01)$, IRAK1 $(P<0.01)$, and $C X C R 1(P<0.01)$ in response to the LPS challenge (Supplemental Figure S1; https://data.mendeley.com/ datasets/77w69zsbp6/2).

Toll-Like Receptor Pathway. At birth, no difference was observed due to maternal treatments for TLR4, BPI, NFKB1, and STAT3 mRNA abundance in whole blood leukocytes after LPS challenge $(P>$ 0.05; Table 3). Analyzing all time points in response to LPS challenge, BPI mRNA abundance was greater overall in whole blood leukocytes from calves born to FOA+CoPectin versus FOA+CoPro cows $(P<0.05$; Table 4 ), coupled with greater abundance in calves 
born to FOA+CoPro versus CoPro cows $(P<0.05$; Table 4). In addition, a Sex effect was observed due to greater $B P I$ mRNA abundance in male versus female calves in response to LPS challenge $(\Delta=-0.44 \pm 0.23$ vs. $-1.01 \pm 0.16 ; P=0.04$; Table 4 ). Regardless of maternal treatments, we observed an Age effect with downregulation of TLR 4 and NFKB1 after LPS challenge $(P<0.01$; Supplemental Figure S2; https://data. mendeley.com/datasets/77w69zsbp6/2).

Adhesion and Migration. At birth, ICAM1 response to the LPS challenge was greater in whole blood leukocytes from calves born to FOA+CoPectin and $\mathrm{FOA}+\mathrm{CoPectin}+\mathrm{RPM}$ versus CoPro cows $(P=$ 0.06; Table 3). In addition, a Sex effect was observed in $C A D M 1(\Delta=0.05 \pm 0.22$ vs. $-0.56 \pm 0.19 ; P=$ 0.04; Table 3) and ITGAM mRNA abundance $(\Delta=$ $0.99 \pm 0.30$ vs. $0.04 \pm 0.26 ; P=0.02$; Table 3 ), due to upregulation in male versus female calves in response to LPS challenge. Analyzing all time points regardless of maternal treatments indicated that ICAM1 and IT$G A M$ were downregulated in response to LPS challenge over time (Age; $P<0.05$; Supplemental Figure S2). In addition, $C A D M 1 \mathrm{mRNA}$ abundance had a different response over time, with an upregulation due to LPS challenge at $21 \mathrm{~d}$ of age (Age; $P=0.03$; Supplemental Figure S2).

Antimicrobial Function. At birth, no difference was observed due to maternal treatments for $L Y Z$, $M P O, N O S 2$, and SOD2 mRNA abundance in whole blood leukocytes after LPS challenge $(P>0.05$; Table 3). Analyzing all time points, a Sex effect was observed in $M P O$ mRNA abundance due to upregulation in male versus female calves in response to LPS challenge $(\Delta$ $=3.99 \pm 0.53$ vs. $2.64 \pm 0.35 ; P=0.03 ;$ Table 4$)$. In addition, mRNA abundance of SOD2 was greater in female versus male calves in response to LPS challenge

Table 3. Effects of maternal supplementation during the last $30 \mathrm{~d}$ of pregnancy with an experimental folic acid source (FOA), 2 cobalt sources [cobalt glucoheptonate (CoPro) or cobalt pectin (CoPectin)], and rumen-protected methionine (RPM) on the response of calf whole blood mRNA abundance to an ex vivo LPS challenge at birth and before colostrum feeding; response calculated as LPS challenged - nonchallenged sample for each calf

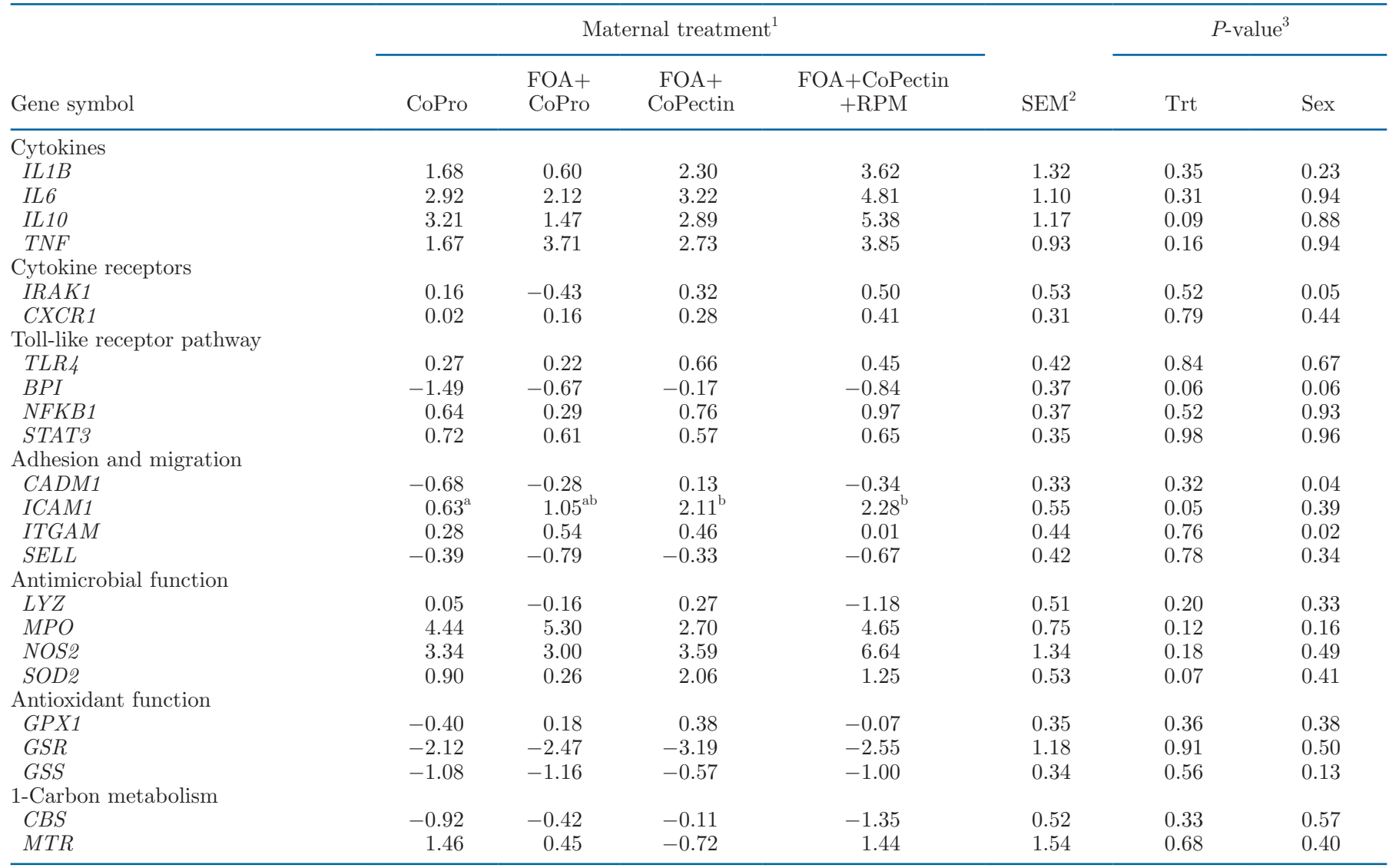

\footnotetext{
${ }^{\mathrm{a}, \mathrm{b}}$ Means within a row differ $(P \leq 0.05)$.

${ }^{1}$ Maternal treatments were CoPro $(\mathrm{n}=12), \mathrm{FOA}+\operatorname{CoPro}(\mathrm{n}=12), \mathrm{FOA}+\operatorname{CoPectin}(\mathrm{n}=12)$, and FOA + CoPectin $+\mathrm{RPM}(\mathrm{n}=12)$.

${ }^{2}$ Greatest standard error of the mean.

${ }^{3}$ Trt $=$ treatment
} 
Table 4. Effects of maternal supplementation during the last $30 \mathrm{~d}$ of pregnancy with an experimental folic acid source (FOA), 2 cobalt sources cobalt glucoheptonate (CoPro) or cobalt pectin (CoPectin)], and rumen-protected methionine (RPM) on calf whole blood mRNA abundance after ex vivo LPS challenge at 0 (at birth and before colostrum feeding), 21, and $42 \mathrm{~d}$ of age (at weaning); response calculated as LPS challenged - nonchallenged sample for each calf

\begin{tabular}{|c|c|c|c|c|c|c|c|c|c|}
\hline \multirow[b]{2}{*}{ Gene symbol } & \multicolumn{4}{|c|}{ Maternal treatment ${ }^{1}$} & \multirow[b]{2}{*}{$\mathrm{SEM}^{2}$} & \multicolumn{4}{|c|}{$P$-value ${ }^{3}$} \\
\hline & CoPro & $\begin{array}{l}\text { FOA+ } \\
\text { CoPro }\end{array}$ & $\begin{array}{l}\text { FOA+ } \\
\text { CoPectin }\end{array}$ & $\begin{array}{c}\mathrm{FOA}+\text { CoPectin } \\
+\mathrm{RPM}\end{array}$ & & Trt & Sex & Age & Trt $\times$ Age \\
\hline \multicolumn{10}{|l|}{ Cytokines } \\
\hline$I L 1 B$ & -0.06 & -1.17 & 0.09 & 1.15 & 1.04 & 0.25 & 0.12 & $<0.01$ & 0.91 \\
\hline IL6 & 2.47 & 1.42 & 2.27 & 2.58 & 1.06 & 0.67 & 0.18 & 0.09 & 0.90 \\
\hline IL10 & 2.13 & 0.66 & 0.97 & 2.69 & 0.93 & 0.11 & 0.58 & $<0.01$ & 0.90 \\
\hline$I R A K 1$ & -0.27 & -0.59 & -0.41 & -0.23 & 0.31 & 0.54 & 0.06 & $<0.01$ & 0.11 \\
\hline \multirow{2}{*}{\multicolumn{10}{|c|}{ Toll-like receptor pathway }} \\
\hline & & & & & & & & & \\
\hline$T L R 4$ & -0.58 & -0.52 & -0.67 & -0.30 & 0.46 & 0.94 & 0.71 & $<0.01$ & 0.69 \\
\hline$B P I$ & $-1.17^{\mathrm{a}}$ & $-1.00^{\mathrm{b}}$ & $-0.76^{\mathrm{c}}$ & $-0.34^{\mathrm{c}}$ & 0.27 & $<0.01$ & 0.04 & 0.98 & 0.28 \\
\hline NFKB1 & -0.06 & -0.29 & -0.34 & 0.30 & 0.28 & 0.27 & 0.44 & $<0.01$ & 0.72 \\
\hline STAT3 & 0.72 & 0.84 & 0.83 & 0.59 & 0.32 & 0.91 & 0.14 & 0.08 & 0.84 \\
\hline \multicolumn{10}{|c|}{ Antimicrobial function } \\
\hline$L Y Z$ & 0.07 & 0.01 & 0.11 & -0.84 & 0.43 & 0.30 & 0.31 & 0.68 & 0.40 \\
\hline$M P O$ & 2.72 & 3.01 & 3.93 & 3.06 & 0.85 & 0.50 & 0.03 & $<0.01$ & 0.06 \\
\hline NOS2 & 3.66 & 2.70 & 3.49 & 4.35 & 1.08 & 0.48 & 0.13 & 0.33 & 0.92 \\
\hline SOD2 & 1.23 & 0.32 & 1.18 & 1.20 & 0.59 & 0.30 & 0.01 & 0.89 & 0.95 \\
\hline \multicolumn{10}{|c|}{ Antioxidant function } \\
\hline$G P X 1$ & -0.47 & -0.36 & -0.37 & -0.76 & 0.25 & 0.56 & 0.73 & $<0.01$ & 0.26 \\
\hline$G S R$ & -4.28 & -2.28 & -3.75 & -4.87 & 1.04 & 0.31 & 0.52 & 0.11 & 0.68 \\
\hline$G S S$ & -1.07 & -1.10 & -1.13 & -1.19 & 0.31 & 0.99 & 0.93 & 0.25 & 0.48 \\
\hline \multicolumn{10}{|c|}{ 1-Carbon metabolism } \\
\hline$C B S$ & -0.35 & -0.13 & -0.20 & -1.14 & 0.36 & 0.12 & 0.94 & $<0.01$ & 0.64 \\
\hline$M T R$ & -0.74 & 1.36 & -2.70 & -2.39 & 1.51 & 0.06 & 0.09 & 0.05 & 0.18 \\
\hline
\end{tabular}

${ }^{\mathrm{a}-\mathrm{c}}$ Means within a row differ $(P \leq 0.05)$.

${ }^{1}$ Maternal treatments were CoPro $(\mathrm{n}=12), \mathrm{FOA}+\operatorname{CoPro}(\mathrm{n}=12)$, FOA + CoPectin $(\mathrm{n}=12)$, and FOA+CoPectin $+\mathrm{RPM}(\mathrm{n}=12)$.

${ }^{2}$ Greatest SEM.

${ }^{3}$ Trt $=$ treatment

$(\Delta=0.19 \pm 0.39$ vs. $1.39 \pm 0.28 ; P=0.01$; Table 4$)$. Regardless of maternal treatments, MPO mRNA abundance decreased over time in response to LPS challenge (Age; $P<0.01$; Supplemental Figure S2).

Antioxidant Function. At birth, no difference was observed due to maternal treatments for GPX1, GSR, and GSS mRNA abundance in whole blood leukocytes after LPS challenge $(P>0.05$; Table 3$)$. Analyzing all time points, regardless of maternal treatments, GPX1 mRNA abundance decreased over time in response to LPS challenge (Age; $P<0.01$; Supplemental Figure S3; https://data.mendeley.com/datasets/77w69zsbp6/2).

1-Carbon Metabolism. At birth, no difference was observed due to maternal treatments for $C B S$ and $M T R$ mRNA abundance in whole blood leukocytes after LPS challenge $(P>0.05$; Table 3$)$. Analyzing all time points regardless of maternal treatments indicated that $M T R$ was overall downregulated in response to LPS challenge over time (Age; $P<0.05$; Supplemental Figure S3). In addition, $C B S$ mRNA abundance had a different response over time, with an upregulation due to LPS challenge at $21 \mathrm{~d}$ of age (Age; $P<0.01$; Supplemental Figure S3).

\section{Whole-Blood Phagocytosis and Oxidative Burst}

After enteropathogenic bacteria challenge, phagocytosis capacity and oxidative burst activity in both neutrophils and monocytes did not differ due to maternal treatment $(P>0.05$; Table 5). Regardless of maternal treatments, an Age effect in response to the challenge was detected for phagocytosis capacity and oxidative burst activity in both neutrophils and monocytes. As calves grew, we observed an increase in the percentage of neutrophils capable of phagocytosis and oxidative burst activity $(P<0.01$; Figure 1$)$. However, although 
Table 5. Effects of maternal supplementation during the last $30 \mathrm{~d}$ of pregnancy with an experimental folic acid source (FOA), 2 cobalt sources [cobalt glucoheptonate (CoPro) or cobalt pectin (CoPectin)], and rumen-protected methionine (RPM) on phagocytosis capacity and oxidative burst activity of calf blood neutrophils and monocytes after enteropathogenic bacteria challenge at 0 (at birth and before colostrum feeding), 21, and 42 days of age (at weaning); data reported as ratio (percentage) of CD14 to CH138A-positive cells with phagocytosis and oxidative burst activity

\begin{tabular}{|c|c|c|c|c|c|c|c|c|c|}
\hline \multirow[b]{2}{*}{$\begin{array}{l}\text { Leukocyte } \\
\text { function }(\%)\end{array}$} & \multicolumn{4}{|c|}{ Maternal treatment ${ }^{1}$} & \multirow[b]{2}{*}{$\mathrm{SEM}^{2}$} & \multicolumn{4}{|c|}{$P$-value ${ }^{3}$} \\
\hline & CoPro & $\begin{array}{l}\text { FOA+ } \\
\text { CoPro }\end{array}$ & $\begin{array}{l}\text { FOA+ } \\
\text { CoPectin }\end{array}$ & $\begin{array}{c}\text { FOA+CoPectin } \\
+\mathrm{RPM}\end{array}$ & & Trt & Sex & Age & Trt $\times$ Age \\
\hline \multicolumn{10}{|l|}{ Neutrophil } \\
\hline Phagocytosis & 66.54 & 66.46 & 71.55 & 74.92 & 2.94 & 0.13 & 0.58 & $<0.01$ & 0.67 \\
\hline Oxidative burst & 60.85 & 61.54 & 62.15 & 64.00 & 2.20 & 0.77 & 0.15 & $<0.01$ & 0.99 \\
\hline \multicolumn{10}{|l|}{ Monocyte } \\
\hline
\end{tabular}

${ }^{1}$ Maternal treatments were CoPro $(\mathrm{n}=12)$, FOA+CoPro $(\mathrm{n}=12)$, FOA+CoPectin $(\mathrm{n}=12)$, and FOA+CoPectin $+\mathrm{RPM}(\mathrm{n}=12)$.

${ }^{2}$ Greatest SEM.

${ }^{3}$ Trt $=$ treatment.

the percentage of monocytes capable of oxidative burst increased over time, the percentage of monocytes capable of phagocytosis decreased at $21 \mathrm{~d}$ of age, coupled with a marked increase at $42 \mathrm{~d}$ of age $(P<0.01$; Figure $1)$.

\section{DISCUSSION}

Work from our group on maternal postruminal Met supply has generated data revealing how this essential AA can affect immune function in the neonatal calf (Jacometo et al., 2015, 2018; Alharthi et al., 2019b). The present study went further than previously to assess for the first time cobalt, FOA, and Met supply. By design, however, rather than using the entire cohort of calves born to cows on study, we focused on those calves for which there was a complete set of performance, mRNA, and immune function data. Combined, our methods allowed us to visualize the dynamics of the neonate immune system at a molecular and cellular level using a noninvasive approach (Hulbert et al., 2011; VailatiRiboni et al., 2017a). The analysis performed at birth before colostrum feeding allowed the closest assessment of in utero effects. In addition, the longitudinal analysis at 0,21 , and $42 \mathrm{~d}$ of age allowed evaluation of carryover effects of maternal exposure to these nutrients.

\section{Acute-Phase Response at Birth}

In cattle, studies have indicated that the positive acute-phase protein haptoglobin could be a candidate biomarker to predict disease (Gånheim et al., 2007; Huzzey et al., 2009). However, although higher levels of haptoglobin indicate a greater degree of inflammation, the sensitivity of haptoglobin concentrations alone as a diagnostic test for individual calves appears to be low (Murray et al., 2014). By binding and eliminating free hemoglobin from the circulation, this protein plays a key role in dampening oxidative and inflammatory stress (Murata et al., 2004). In the present study, the lower haptoglobin concentrations observed at birth in FOA+CoPro versus CoPro calves indicated that an additive effect of FOA might have contributed to reducing the inflammatory status. Although data in calves is lacking, a recent study in pregnant women demonstrated that $\mathrm{B}_{12}$ in addition to FOA and iron supplementation decreased plasma haptoglobin during the postintervention period (Zec et al., 2020). Previous work in humans and rodents investigating the immunomodulatory role of FOA, isolated or combined with other methyl donors (e.g., Met, choline, and $\mathrm{B}_{12}$ ), underscored the effects of FOA on anti-inflammatory responses directly as a result of blocking proinflammatory cytokine expression and production, such as tumor necrosis factor- $\alpha$ (Chen et al., 2016; Cianciulli et al., 2016; Samblas et al., 2018). Specific mechanisms for responses detected in the present study still need to be investigated in future, more controlled studies. Although previous work from our group and others demonstrated lower haptoglobin levels due to increased methyl donor supply in cows during the transition (Coleman et al., 2020) and lategestation periods (Jacometo et al., 2018), no studies currently report specifically the role of additional FOA on anti-inflammatory regulation in ruminants.

Among positive acute-phase proteins, ceruloplasmin is a serum ferroxidase that contains most of the blood plasma copper (Hellman and Gitlin, 2002). Its serum concentrations increase considerably during inflammation, infection, and trauma, mainly due to an increase in gene transcription through cytokine stimulation of liver cells (Gitlin, 1988). The trend observed for lower ceruloplasmin concentration in $\mathrm{FOA}+\mathrm{CoPectin}+\mathrm{RPM}$ versus FOA+CoPectin calves is an example of the additive effect of this essential AA as a possible regulator 


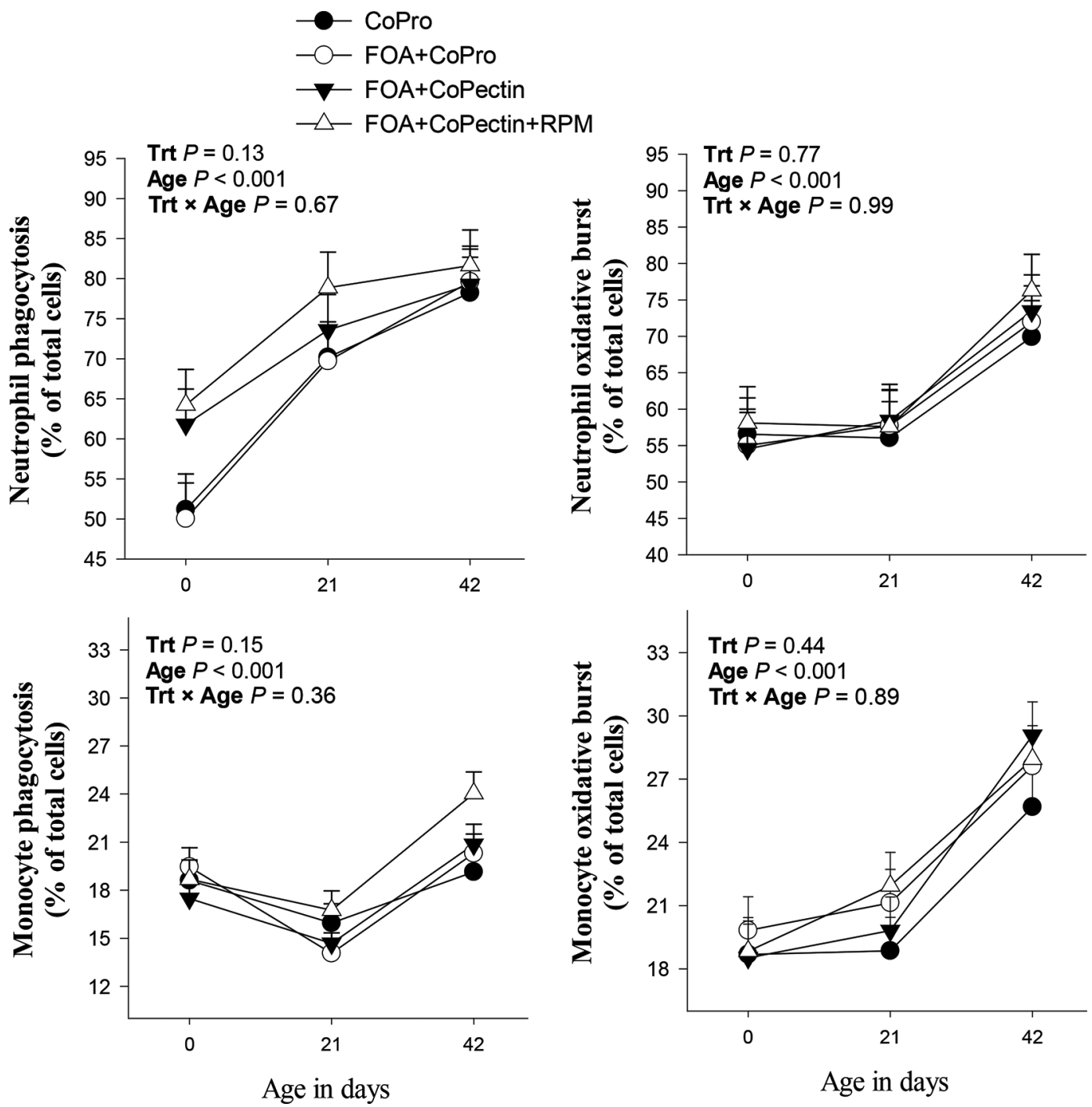

Figure 1. Ex vivo phagocytosis capacity and oxidative burst activity of blood neutrophils and monocytes from Holstein calves born to cows after enteropathogenic bacteria challenge. Multiparous Holstein cows were fed during the last $30 \mathrm{~d}$ of pregnancy an experimental folic acid source (FOA), 2 cobalt sources [cobalt glucoheptonate (CoPro) or cobalt pectin (CoPectin)], and rumen-protected methionine (RPM). Maternal treatments were CoPro $(\mathrm{n}=12)$, FOA+CoPro $(\mathrm{n}=12)$, FOA+CoPectin $(\mathrm{n}=12)$, and FOA+CoPectin+RPM $(\mathrm{n}=12)$. Trt $=$ treatment effect. Error bars indicate SEM.

of inflammatory mechanisms (Coleman et al., 2020). The fact that effects of additional RPM only were associated with lower ceruloplasmin levels at birth, without altering other acute-phase proteins, could suggest it had little biological consequence. However, these results, along with our previous studies demonstrating that maternal supplementation with RPM during late pregnancy promoted a lower inflammatory status in the offspring (Jacometo et al., 2016; Alharthi et al., 2019b; Coleman et al., 2021), support data from nonruminants underscoring the immunomodulatory properties of Met (Wang et al., 2018).

\section{Whole-Blood Molecular Responses to LPS Challenge}

The ICAM1 gene encodes the cell surface glycoprotein intercellular adhesion molecule 1 (ICAM1), which acts as a membrane-bound molecule involved in cell-to-cell adhesive interactions on leukocyte adhesion and migration (Zhou et al., 2018). Data underscoring a greater mRNA abundance of ICAM1 in response to LPS challenge at birth in calves born to FOA+CoPectin and $\mathrm{FOA}+\mathrm{CoPectin}+\mathrm{RPM}$ versus CoPro cows are challenging to explain physiologically. An additive effect of FOA could partly help explain the response, because 
some studies in humans reported a relationship between B-vitamin supply (FOA and $\mathrm{B}_{12}$ ) and regulation of biomarkers related to endothelial function (Alian et al., 2012; van Dijk et al., 2016). However, the same behavior was not observed in FOA+CoPro calves. In this sense, the absence of transcriptional regulation due to maternal treatment in other important adhesion and migration-related genes (e.g., CADM1, ITGAM, and $S E L L)$ also should be taken into account. Thus, it appears that biological consequences of ICAM1 upregulation in the context of chemotaxis, migration, and adhesion processes would have been a dampening of these events.

Bactericidal permeability-increasing protein (BPI), encoded by $B P I$, plays a central role in immune recognition and binding to LPS (Bülow et al., 2018). At least in nonruminants, LPS-binding protein (LBP) and BPI interactions with cell surface molecules (e.g., CD14) are the major pathway by which PMN recognize low concentrations of LPS and begin stimuli to respond against gram-negative bacteria (Ryu et al., 2017; Bülow et al., 2018). In nonruminants, trace amounts of LPS are sufficient to activate NF- $\kappa \beta$ via TLR4 and its translocation to the nucleus, stimulating cytokine-related gene expression (e.g., IL1B, IL6, and TNF; Hayden and Ghosh, 2011). Among toll-like receptor pathway genes evaluated, it is noteworthy that transcriptional regulation due to maternal treatments was observed only for BPI. However, at the transcriptional level, this effect did not seem to affect the cell signaling cascade (e.g., TLR4, NFKB1, and cytokine-related genes). In this sense, with the lack of effects on receptors, transcription factors, and proinflammatory cytokines, it is challenging to speculate on the biological significance of greater $B P I$ abundance in calves born to $\mathrm{FOA}+\mathrm{CoPro}$ versus CoPro and $\mathrm{FOA}+\mathrm{CoPectin}$ versus $\mathrm{FOA}+\mathrm{CoPro}$ cows. In addition, how much of the observed FOA effect was due to an increase in maternal ruminal supply of FOA cannot be determined, nor whether 1 of the 2 different cobalt sources was able to promote marked effects on immune system activation against LPS.

The IL10 gene encodes interleukin-10 (IL-10), which is an anti-inflammatory cytokine produced by monocytes, macrophages, dendritic cells, and lymphocytes (Rutz and Ouyang, 2016). Among cytokine-related genes, IL10 was the sole gene with a possible regulation due to a trend observed in calves born to cows fed additional RPM. Our research group recently demonstrated upregulation of IL10 mRNA abundance in isolated PMN from lactating Holstein cows and calves (Abdelmegeid et al., 2017) as level of Met supply increased (Lopreiato et al., 2019; Vailati-Riboni et al., 2019). Thus, the trend observed with marked IL10 upregulation in calves born from RPM cows in response to LPS challenge at birth underscored the importance of this AA as an immunomodulator (Coleman et al., 2020, 2021). Overall, combined results suggested that Met might play an important role in the modulation of IL10, especially during immune challenges.

\section{Whole-Blood Cellular Responses to Enteropathogenic Bacteria Challenge}

It is noteworthy that the present study was unable to demonstrate the potential for greater maternal supply of methyl donors to influence cellular immune function. Although our group has demonstrated effects of maternal RPM supply on calf phagocytosis capability (Alharthi et al., 2019b), similar responses were not observed in the present study. Furthermore, a recent study evaluating effects of supplementation with FOA and $\mathrm{B}_{12}$ on leukocyte function in Holstein cows did not detect differences on phagocytosis and oxidative burst activity (Vanacker et al., 2020). However, the numerically greater percentage $(+11.7 \%)$ of neutrophils capable of phagocytosis detected in calves from $\mathrm{FOA}+\mathrm{CoPectin}$ versus $\mathrm{FOA}+\mathrm{CoPro}$ cows, especially at birth, was surprising. Whether numerical effects arose from greater availability in utero of $\mathrm{B}_{12}$ synthesized from cobalt by rumen microbes remains to be determined. A classic study in humans reported lower metabolic activity in leukocytes from patients with $\mathrm{B}_{12}$ deficiency during an in vitro phagocytosis assay (Kaplan and Basford, 1976). In ruminants, however, these types of relationships have not yet been clarified. Thus, our data underscored that, despite a numerical difference in neutrophil phagocytosis capacity, these responses did not result in an improvement of innate cell killing capabilities, due to the lack of differences observed in oxidative burst activity. Available data from previous studies and the present study offer support for more in-depth mechanistic studies.

\section{Temporal Responses}

The downregulation in mRNA abundance after LPS challenge for most genes related to cytokines and cytokine receptors $(I L 1 B, I L 6, I L 10, T N F, I R A K 1$, CXCR1), toll-like receptor pathway (TLR 4, NFKB1), adhesion and migration (ICAM1, ITGAM), antimicrobial function $(M P O)$, and antioxidant function (GPX1) was likely due to changes in endocrine and cellular profiles as calves aged (Gao et al., 2012). A limitation in the present study is that we did not perform a differential leukocyte count in whole blood samples. Thus, we cannot determine with certainty whether the observed differences were due to changes in function or were merely a reflection of changes in leukocyte 
populations. However, it is well established that, in healthy conditions, newborn calves experience a change in proportions of blood leukocyte populations during the neonatal period (Tornquist and Rigas, 2010; Marcato et al., 2018). For instance, at birth, a predominant population of PMN begins to be replaced over time by peripheral blood mononuclear cells - mainly lymphocytes (Jones and Allison, 2007). Because PMN are the main effector cells of the immediate innate response to LPS, the lower abundance of this cell type in calves at 21 and $42 \mathrm{~d}$ of age might have been a limiting factor for the responses observed at these time points. Similar molecular responses were also reported in our previous work with whole blood and isolated PMN from Holstein calves during the first few weeks of life (Osorio et al., 2013b; Jacometo et al., 2018; Alharthi et al., 2019b). Together, those data indicated that the calf immune system at birth and before colostrum feeding is more sensitive to LPS challenge, compared with later stages of development (i.e., d 21 and 42 of age; Lopes et al., 2021).

Regardless of maternal treatments, aside from alterations in cellular profiles, differences in longitudinal immune function and mRNA abundance after LPS challenge can be explained partly through the characteristics of antigens in each type of analysis. Because the immune function assay was performed with peripheral blood neutrophils and monocytes stimulated with E. coli (Hulbert et al., 2011), a distinct pattern of response as calves grew might have occurred due to maturation of the innate immune system (e.g., effector cells and complement system) and acquisition of maternal antibodies after colostrum intake (Chase et al., 2008; Batista et al., 2015; Hulbert and Moisá, 2016). Although the assessment of adequate transfer of passive immunity was not undertaken through IgG or serum total protein concentrations at 2 and $7 \mathrm{~d}$ of age, an important limitation of the study, we ensured that all calves received the same amount of colostrum from their respective dams. It is well known that antibodies act as important opsonins to facilitate phagocytosis (Winkelstein, 1973). In this sense, in addition to greater cell maturity of neutrophils and monocytes after the first few weeks of life, the presence of maternal antibodies promoting opsonization of enteropathogenic bacteria might have played a role in the overall greater percentage of cells capable of phagocytosis and oxidative burst activity over time (Seto et al., 1976; Menge et al., 1998).

\section{Sex-Specific Responses}

Although our group recently reported that increased methyl donor supply during late pregnancy led to off- spring sex-specific divergent changes in metabolic and epigenetic signatures in the bovine placenta (Batistel et al., 2019), knowledge about sex-specific gene expression and metabolic control in ruminants is still in its infancy. Previous studies underscored that gene expression with a "sex bias" is predominant in many species, and the extent to which this occurs can vary greatly among tissues or stages of development (Grath and Parsch, 2016). For instance, a recent study across human tissues revealed a repertoire of transcription factors that play important roles in the sex-specific architecture of gene regulatory networks in both health and disease (Lopes-Ramos et al., 2020). The few differences detected in the present study due to sex led us to speculate that female calves experienced some degree of oxidative stress at birth, such as increased paraoxonase, total reactive oxygen metabolites, nitrite, $\beta$-carotene, and haptoglobin. In contrast, the upregulation of IRAK1, $C A D M 1$, and ITGAM in response to LPS challenge at birth in male calves suggested a greater capacity for signaling and cell adhesion. Clearly, the present study does not truly allow to ascertain the long-term biological effects of the sex-specific differences detected. However, we believe that these data are important in terms of follow-up studies, because the field of micronutrient supplementation in the overall context of managing the pregnant cow is certain to continue growing (see review by Coleman et al., 2021).

\section{CONCLUSIONS}

Despite some inherent limitations in evaluating data from a retrospective selection of calves, the fact that animals used had a complete set of performance, mRNA, and innate immune function data allows for a preliminary evaluation of the role of maternal cobalt, folic acid, and Met supply. Although a few plasma and molecular biomarkers were significantly affected, at the levels fed in the present study, the data did not provide clear evidence of beneficial effects of nutrients associated with 1-carbon metabolism in modulating cellular immune functionality of the neonatal calf. Further studies with greater biological power and different dosages of these nutrients could help ascertain the existence of mechanistic relationships that have implications for calf growth and development.

\section{ACKNOWLEDGMENTS}

M. Gomes Lopes was supported in part by a fellowship from Coordenação de Aperfeiçoamento de Pessoal de Nível Superior - Brazil (CAPES, finance Code 001) and by Hatch funds under project ILLU-538-914, National Institute of Food and Agriculture (Washington, 
DC). A. S. Alharthi received a fellowship from King Saud University to perform his PhD studies at the University of Illinois (Urbana). Y. Liang and H. Dai were recipients of doctoral fellowships from China Scholarship Council (Beijing, China) to perform $\mathrm{PhD}$ studies at the University of Illinois (Urbana). E. Abdel-Hamied was supported by a postdoctoral fellowship from the government of the Arab Republic of Egypt. We thank Perdue AgriBusiness for the donation of ProvAAL2 AADvantage during the course of the experiment. We also thank ADM Animal Nutrition for the donation of SoyChlor during the course of the experiment. Zinpro Corporation had a role in the study design and provided financial support to cover costs of animal use, data collection, and sample analyses. The cobalt pectin and folic acid products used in this study are products in development at Zinpro Corporation, and it is the intent of Zinpro Corporation to eventually commercialize the cobalt pectin product and a folic acid product. One of the authors of this paper, M. T. Socha, is an employee of Zinpro Corporation. The authors have not stated any other conflicts of interest.

\section{REFERENCES}

Abdelmegeid, M. K., M. Vailati-Riboni, A. Alharthi, F. Batistel, and J. J. Loor. 2017. Supplemental methionine, choline, or taurine alter in vitro gene network expression of polymorphonuclear leukocytes from neonatal Holstein calves. J. Dairy Sci. 100:3155-3165. https://doi.org/10.3168/jds.2016-12025.

Alharthi, A. S., F. Batistel, M. K. Abdelmegeid, G. Lascano, C. Parys, A. Helmbrecht, E. Trevisi, and J. J. Loor. 2018. Maternal supply of methionine during late-pregnancy enhances rate of Holstein calf development in utero and postnatal growth to a greater extent than colostrum source. J. Anim. Sci. Biotechnol. 9:83. https://doi .org/10.1186/s40104-018-0298-1.

Alharthi, A. S., D. N. Coleman, Y. Liang, F. Batistel, A. A. Elolimy, R. C. Yambao, E. Abdel-Hamied, Y. X. Pan, C. Parys, I. A. Alhidary, M. M. Abdelrahman, and J. J. Loor. 2019a. Hepatic 1-carbon metabolism enzyme activity, intermediate metabolites, and growth in neonatal Holstein dairy calves are altered by maternal supply of methionine during late pregnancy. J. Dairy Sci. 102:10291-10303. https://doi.org/10.3168/jds.2019-16562.

Alharthi, A. S., V. Lopreiato, H. Dai, R. Bucktrout, M. Abdelmegeid, F. Batistel, C. Parys, X. Shen, M. A. Ballou, E. Trevisi, I. A. Alhidary, M. M. Abdelrahman, and J. J. Loor. 2019b. Short communication: Supply of methionine during late pregnancy enhances whole-blood innate immune response of Holstein calves partly through changes in mRNA abundance in polymorphonuclear leukocytes. J. Dairy Sci. 102:10599-10605. https://doi.org/10.3168/ jds.2018-15676.

Alian, Z., M. Hashemipour, E. H. Dehkordi, S. Hovsepian, M. Amini, M. H. Moadab, and S. H. Javanmard. 2012. The effects of folic acid on markers of endothelial function in patients with type 1 diabetes mellitus. Med. Arh. 66:12-15. https://doi.org/10.5455/ medarh.2012.66.12-15.

Arshad, U., M. G. Zenobi, C. R. Staples, and J. E. P. Santos. 2020. Meta-analysis of the effects of supplemental rumen-protected choline during the transition period on performance and health of parous dairy cows. J. Dairy Sci. 103:282-300. https://doi.org/10 .3168/jds.2019-16842.

Batista, C. F., M. G. Blagitz, H. G. Bertagnon, R. C. Gomes, K. R. Santos, and A. M. M. P. Della Libera. 2015. Evolution of phago- cytic function in monocytes and neutrophils blood cells of healthy calves. J. Dairy Sci. 98:8882-8888. https://doi.org/10.3168/jds .2015-9573.

Batistel, F., A. S. Alharthi, R. R. C. Yambao, A. A. Elolimy, Y. X. Pan, C. Parys, and J. J. Loor. 2019. Methionine supply during late-gestation triggers offspring sex-specific divergent changes in metabolic and epigenetic signatures in bovine placenta. J. Nutr. 149:6-17. https://doi.org/10.1093/jn/nxy240.

Batistel, F., J. M. Arroyo, C. I. M. Garces, E. Trevisi, C. Parys, M. A. Ballou, F. C. Cardoso, and J. J. Loor. 2018. Ethyl-cellulose rumen-protected methionine alleviates inflammation and oxidative stress and improves neutrophil function during the periparturient period and early lactation in Holstein dairy cows. J. Dairy Sci. 101:480-490. https://doi.org/10.3168/jds.2017-13185.

Benzie, I. F., and J. J. Strain. 1996. The ferric reducing ability of plasma (FRAP) as a measure of "antioxidant power": The FRAP assay. Anal. Biochem. 239:70-76. https://doi.org/10.1006/abio .1996 .0292 .

Bertoni, G., E. Trevisi, X. Han, and M. Bionaz. 2008. Effects of inflammatory conditions on liver activity in puerperium period and consequences for performance in dairy cows. J. Dairy Sci. 91:33003310. https://doi.org/10.3168/jds.2008-0995.

Bionaz, M., E. Trevisi, L. Calamari, F. Librandi, A. Ferrari, and G. Bertoni. 2007. Plasma paraoxonase, health, inflammatory conditions, and liver function in transition dairy cows. J. Dairy Sci. 90:1740-1750. https://doi.org/10.3168/jds.2006-445.

Bouchard, L., S. Blais, C. Desrosiers, X. Zhao, and P. Lacasse. 1999. Nitric oxide production during endotoxin-induced mastitis in the cow. J. Dairy Sci. 82:2574-2581. https://doi.org/10.3168/jds .S0022-0302(99)75512-8.

Bradley, P. P., D. A. Priebat, R. D. Christensen, and G. Rothstein. 1982. Measurement of cutaneous inflammation: Estimation of neutrophil content with an enzyme marker. J. Invest. Dermatol. 78:206-209. https://doi.org/10.1111/1523-1747.ep12506462.

Bülow, S., L. Zeller, M. Werner, M. Toelge, J. Holzinger, C. Entzian, T. Schubert, F. Waldow, N. Gisch, S. Hammerschmidt, and A. Gessner. 2018. Bactericidal/permeability-increasing protein is an enhancer of bacterial lipoprotein recognition. Front. Immunol. 9:2768. https://doi.org/10.3389/fimmu.2018.02768.

Chase, C. C. L., D. J. Hurley, and A. J. Reber. 2008. Neonatal immune development in the calf and its impact on vaccine response. Vet. Clin. North Am. Food Anim. Pract. 24:87-104. https://doi.org/10 .1016/j.cvfa.2007.11.001.

Chen, H., S. Liu, L. Ji, T. Wu, Y. Ji, Y. Zhou, M. Zheng, M. Zhang, W. Xu, and G. Huang. 2016. Folic acid supplementation mitigates Alzheimer's disease by reducing inflammation: A randomized controlled trial. Mediators Inflamm. 2016:1-10. https://doi.org/10 $.1155 / 2016 / 5912146$.

Cianciulli, A., R. Salvatore, C. Porro, T. Trotta, and M. A. Panaro. 2016. Folic acid is able to polarize the inflammatory response in LPS activated microglia by regulating multiple signaling pathways. Mediators Inflamm. 2016:1-10. https://doi.org/10.1155/ 2016/5240127.

Coleman, D. N., A. S. Alharthi, Y. Liang, M. G. Lopes, V. Lopreiato, M. Vailati-Riboni, and J. J. Loor. 2021. Multifaceted role of one-carbon metabolism on immunometabolic control and growth during pregnancy, lactation and neonatal period in dairy cattle. J. Anim. Sci. Biotechnol. 12:27. https://doi.org/10.1186/s40104 $-021-00547-5$.

Coleman, D. N., V. Lopreiato, A. S. Alharthi, and J. J. Loor. 2020. Amino acids and the regulation of oxidative stress and immune function in dairy cattle. J. Anim. Sci. 98 (Suppl. 1):S175-S193. https://doi.org/10.1093/jas/skaa138.

Duplessis, M., and C. L. Girard. 2019. Effect of maternal biotin, folic acid, and vitamin $\mathrm{B}_{12}$ supplementation before parturition on colostral and Holstein calf plasma concentrations in those vitamins. Anim. Feed Sci. Technol. 256:114241. https://doi.org/10.1016/j .anifeedsci.2019.114241.

Gånheim, C., S. Alenius, and K. Persson Waller. 2007. Acute phase proteins as indicators of calf herd health. Vet. J. 173:645-651. https://doi.org/10.1016/j.tvjl.2006.01.011. 
Gao, F., Y. C. Liu, Z. H. Zhang, C. Z. Zhang, H. W. Su, and S. L. Li. 2012. Effect of prepartum maternal energy density on the growth performance, immunity, and antioxidation capability of neonatal calves. J. Dairy Sci. 95:4510-4518. https://doi.org/10.3168/jds .2011-5087.

Gilliam, M. B., M. P. Sherman, J. M. Griscavage, and L. J. Ignarro. 1993. A spectrophotometric assay for nitrate using NADPH oxidation by Aspergillus nitrate reductase. Anal. Biochem. 212:359-365. https://doi.org/10.1006/abio.1993.1341.

Girard, C. L., and J. J. Matte. 2005. Folic acid and vitamin $\mathrm{B}_{12}$ requirements of dairy cows: A concept to be revised. Livest. Prod. Sci. 98:123-133. https://doi.org/10.1016/j.livprodsci.2005.10.009.

Girard, C. L., J. J. Matte, and G. F. Tremblay. 1995. Gestation and lactation of dairy cows: A role for folic acid? J. Dairy Sci. 78:404411. https://doi.org/10.3168/jds.S0022-0302(95)76649-8.

Gitlin, J. D. 1988. Transcriptional regulation of ceruloplasmin gene expression during inflammation. J. Biol. Chem. 263:6281-6287. https://doi.org/10.1016/S0021-9258(18)68783-6.

Grath, S., and J. Parsch. 2016. Sex-biased gene expression. Annu. Rev. Genet. 50:29-44. https://doi.org/10.1146/annurev-genet-120215 -035429 .

Graulet, B., J. J. Matte, A. Desrochers, L. Doepel, M. F. Palin, and C. L. Girard. 2007. Effects of dietary supplements of folic acid and vitamin $\mathrm{B}_{12}$ on metabolism of dairy cows in early lactation. J. Dairy Sci. 90:3442-3455. https://doi.org/10.3168/jds.2006-718.

Hayden, M. S., and S. Ghosh. 2011. NF- $\kappa$ B in immunobiology. Cell Res. 21:223-244. https://doi.org/10.1038/cr.2011.13.

Hellman, N. E., and J. D. Gitlin. 2002. Ceruloplasmin metabolism and function. Annu. Rev. Nutr. 22:439-458. https://doi.org/10.1146/ annurev.nutr.22.012502.114457.

Hulbert, L. E., J. A. Carroll, N. C. Burdick, R. D. Randel, M. S. Brown, and M. A. Ballou. 2011. Innate immune responses of temperamental and calm cattle after transportation. Vet. Immunol. Immunopathol. 143:66-74. https://doi.org/10.1016/j.vetimm.2011 .06 .025 .

Hulbert, L. E., and S. J. Moisá. 2016. Stress, immunity, and the management of calves. J. Dairy Sci. 99:3199-3216. https://doi.org/10 $.3168 /$ jds.2015-10198.

Huzzey, J. M., T. F. Duffield, S. J. LeBlanc, D. M. Veira, D. M. Weary, and M. A. G. Von Keyserlingk. 2009. Short communication: Haptoglobin as an early indicator of metritis. J. Dairy Sci. 92:621-625. https://doi.org/10.3168/jds.2008-1526.

Jacometo, C. B., A. S. Alharthi, Z. Zhou, D. Luchini, and J. J. Loor. 2018. Maternal supply of methionine during late pregnancy is associated with changes in immune function and abundance of microRNA and mRNA in Holstein calf polymorphonuclear leukocytes. J. Dairy Sci. 101:8146-8158. https://doi.org/10.3168/jds 2018-14428.

Jacometo, C. B., J. S. Osorio, M. Socha, M. N. Corrêa, F. PiccioliCappelli, E. Trevisi, and J. J. Loor. 2015. Maternal consumption of organic trace minerals alters calf systemic and neutrophil mRNA and microRNA indicators of inflammation and oxidative stress. J. Dairy Sci. 98:7717-7729. https://doi.org/10.3168/jds.2015-9359.

Jacometo, C. B., Z. Zhou, D. Luchini, M. N. Corrêa, and J. J. Loor. 2017. Maternal supplementation with rumen-protected methionine increases prepartal plasma methionine concentration and alters hepatic mRNA abundance of 1-carbon, methionine, and transsulfuration pathways in neonatal Holstein calves. J. Dairy Sci. 100:3209-3219. https://doi.org/10.3168/jds.2016-11656.

Jacometo, C. B., Z. Zhou, D. Luchini, E. Trevisi, M. N. Corrêa, and J. J. Loor. 2016. Maternal rumen-protected methionine supplementation and its effect on blood and liver biomarkers of energy metabolism, inflammation, and oxidative stress in neonatal Holstein calves. J. Dairy Sci. 99:6753-6763. https://doi.org/10.3168/ jds.2016-11018.

Jahan, N., A. Minuti, and E. Trevisi. 2015. Assessment of immune response in periparturient dairy cows using ex vivo whole blood stimulation assay with lipopolysaccharides and carrageenan skin test. Vet. Immunol. Immunopathol. 165:119-126. https://doi.org/ 10.1016/j.vetimm.2015.04.003.
Jones, M. L., and R. W. Allison. 2007. Evaluation of the ruminant complete blood cell count. Vet. Clin. North Am. Food Anim. Pract. 23:377-402. https://doi.org/10.1016/j.cvfa.2007.07.002.

Kaplan, S.S., and R.R. Basford. 1976. Effect of vitamin $\mathrm{B}_{12}$ and folic acid deficiencies on neutrophil function. Blood 47:801-805.

Liang, Y., F. Batistel, C. Parys, and J. J. Loor. 2019. Methionine supply during the periparturient period enhances insulin signaling, amino acid transporters, and mechanistic target of rapamycin pathway proteins in adipose tissue of Holstein cows. J. Dairy Sci. 102:4403-4414. https://doi.org/10.3168/jds.2018-15738.

Ling, T., M. Hernandez-Jover, L. M. Sordillo, and A. Abuelo. 2018. Maternal late-gestation metabolic stress is associated with changes in immune and metabolic responses of dairy calves. J. Dairy Sci. 101:6568-6580. https://doi.org/10.3168/jds.2017-14038.

Lopes, M. G., A. S. Alharthi, V. Lopreiato, E. Abdel-Hamied, Y Liang, D. N. Coleman, H. Dai, M. N. Corrêa, C. Fernandez, and J. J. Loor. 2021. Maternal body condition influences neonatal calf whole blood innate-immune molecular responses to ex vivo lipopolysaccharide challenge. J. Dairy Sci. 104:2266-2279.

Lopes-Ramos, C. M., C. Y. Chen, M. L. Kuijjer, J. N. Paulson, A. R. Sonawane, M. Fagny, J. Platig, K. Glass, J. Quackenbush, and D. L. DeMeo. 2020. Sex differences in gene expression and regulatory networks across 29 human tissues. Cell Rep. 31:107795. https:// doi.org/10.1016/j.celrep.2020.107795.

Lopreiato, V., M. Vailati-Riboni, A. Bellingeri, I. Khan, G. Farina, C. Parys, and J. J. Loor. 2019. Inflammation and oxidative stress transcription profiles due to in vitro supply of methionine with or without choline in unstimulated blood polymorphonuclear leukocytes from lactating Holstein cows. J. Dairy Sci. 102:10395-10410. https://doi.org/10.3168/jds.2019-16413.

Lucock, M. 2000. Folic acid: Nutritional biochemistry, molecular biology, and role in disease processes. Mol. Genet. Metab. 71:121-138. https://doi.org/10.1006/mgme.2000.3027.

Marcato, F., H. van den Brand, B. Kemp, and K. van Reenen. 2018. Evaluating potential biomarkers of health and performance in veal calves. Front. Vet. Sci. 5:133. https://doi.org/10.3389/fvets.2018 .00133

Menge, C., B. Neufeld, W. Hirt, N. Schmeer, R. Bauerfeind, G. Baljer, and L. H. Wieler. 1998. Compensation of preliminary blood phagocyte immaturity in the newborn calf. Vet. Immunol. Immunopathol. 62:309-321. https://doi.org/10.1016/S0165-2427(98)00109 $-3$.

Murata, H., N. Shimada, and M. Yoshioka. 2004. Current research on acute phase proteins in veterinary diagnosis: An overview. Vet. J. 168:28-40. https://doi.org/10.1016/S1090-0233(03)00119-9.

Murray, C. F., M. C. Windeyer, T. F. Duffield, D. B. Haley, D. L. Pearl, K. M. Waalderbos, and K. E. Leslie. 2014. Associations of serum haptoglobin in newborn dairy calves with health, growth, and mortality up to 4 months of age. J. Dairy Sci. 97:7844-7855. https://doi.org/10.3168/jds.2014-8465.

Osorio, J. S., P. Ji, J. K. Drackley, D. Luchini, and J. J. Loor. 2013a. Supplemental Smartamine M or MetaSmart during the transition period benefits postpartal cow performance and blood neutrophil function. J. Dairy Sci. 96:6248-6263. https://doi.org/10.3168/jds .2012-5790.

Osorio, J. S., E. Trevisi, M. A. Ballou, G. Bertoni, J. K. Drackley, and J. J. Loor. 2013b. Effect of the level of maternal energy intake prepartum on immunometabolic markers, polymorphonuclear leukocyte function, and neutrophil gene network expression in neonatal Holstein heifer calves. J. Dairy Sci. 96:3573-3587. https://doi.org/ $10.3168 /$ jds.2012-5759.

Osorio, J. S., R. L. Wallace, D. J. Tomlinson, T. J. Earleywine, M. T. Socha, and J. K. Drackley. 2012. Effects of source of trace minerals and plane of nutrition on growth and health of transported neonatal dairy calves. J. Dairy Sci. 95:5831-5844. https://doi.org/ 10.3168/jds.2011-5042.

Preynat, A., H. Lapierre, M. C. Thivierge, M. F. Palin, N. Cardinault, J. J. Matte, A. Desrochers, and C. L. Girard. 2010. Effects of supplementary folic acid and vitamin $\mathrm{B}_{12}$ on hepatic metabolism of dairy cows according to methionine supply. J. Dairy Sci. 93:21302142. https://doi.org/10.3168/jds.2009-2796. 
Rutz, S., and W. Ouyang. 2016. Regulation of interleukin-10 expression. Pages 89-116 in Regulation of Cytokine Gene Expression in Immunity and Diseases, Advances in Experimental Medicine and Biology. X. Ma, ed. Springer Science. https://doi.org/10.1007/978 -94-024-0921-5.

Ryu, J. K., S. J. Kim, S. H. Rah, J. I. Kang, H. E. Jung, D. Lee, H. K. Lee, J. O. Lee, B. S. Park, T. Y. Yoon, and H. M. Kim. 2017. Reconstruction of LPS transfer cascade reveals structural determinants within LBP, CD14, and TLR4-MD2 for efficient LPS recognition and transfer. Immunity 46:38-50. https://doi.org/10.1016/ j.immuni.2016.11.007.

Samblas, M., J. A. Martínez, and F. Milagro. 2018. Folic acid improves the inflammatory response in LPS-activated THP-1 macrophages. Mediators Inflamm. 2018:1-8. https://doi.org/10.1155/ 2018/1312626.

Seto, A., T. Okabe, N. Sasaki, and Y. Ito. 1976. Opsonic activity and O-agglutinins against Escherichia coli in bovine colostrum. Am. J. Vet. Res. 37:635-638.

Stemme, K., P. Lebzien, G. Flachowsky, and H. Scholz. 2008. The influence of an increased cobalt supply on ruminal parameters and microbial vitamin $B_{12}$ synthesis in the rumen of dairy cows. Arch. Anim. Nutr. 62:207-218.

Tornquist, S. J., and J. Rigas. 2010. Interpretation of ruminant leukocyte responses. Pages 307-313 in Schalm's Veterinary Hematology. D. J. Weiss and K. J. Wardrop, ed. Blackwell Publishing Ltd.

Trevisi, E., M. Amadori, S. Cogrossi, E. Razzuoli, and G. Bertoni. 2012. Metabolic stress and inflammatory response in high-yielding, periparturient dairy cows. Res. Vet. Sci. 93:695-704. https://doi .org/10.1016/j.rvsc.2011.11.008.

Trevisi, E., G. Bertoni, R. Lombardelli, and A. Minuti. 2013. Relation of inflammation and liver function with the plasma cortisol response to adrenocorticotropin in early lactating dairy cows. J. Dairy Sci. 96:5712-5722. https://doi.org/10.3168/jds.2012-6375.

Vailati-Riboni, M., J. S. Osorio, E. Trevisi, D. Luchini, and J. J. Loor. 2017a. Supplemental Smartamine M in higher-energy diets during the prepartal period improves hepatic biomarkers of health and oxidative status in Holstein cows. J. Anim. Sci. Biotechnol. 8:17. https://doi.org/10.1186/s40104-017-0147-7.

Vailati-Riboni, M., T. Xu, B. Qadir, R. Bucktrout, C. Parys, and J. J. Loor. 2019. In vitro methionine supplementation during lipopolysaccharide stimulation modulates immunometabolic gene network expression in isolated polymorphonuclear cells from lactating Holstein cows. J. Dairy Sci. 102:8343-8351. https://doi.org/10.3168/ jds.2018-15737.

Vailati-Riboni, M., Z. Zhou, C. B. Jacometo, A. Minuti, E. Trevisi, D. N. Luchini, and J. J. Loor. 2017b. Supplementation with rumen-protected methionine or choline during the transition period influences whole-blood immune response in periparturient dairy cows. J. Dairy Sci. 100:3958-3968. https://doi.org/10.3168/jds .2016-11812.

van Dijk, S. C., A. W. Enneman, K. M. A. Swart, J. P. Van Wijngaarden, A. C. Ham, R. De Jonge, H. J. Blom, E. J. Feskens, J. M. Geleijnse, N. M. Van Schoor, R. A. M. Dhonukshe-Rutten, R. T. De Jongh, P. Lips, L. C. P. G. M. De Groot, A. G. Uitterlinden, T. H. Van Den Meiracker, F. U. S. Mattace-Raso, N. Van Der Velde, and Y. M. Smulders. 2016. Effect of vitamin $B_{12}$ and folic acid supplementation on biomarkers of endothelial function and inflammation among elderly individuals with hyperhomocysteinemia. Vasc. Med. 21:91-98. https://doi.org/10.1177/1358863X15622281.
Vanacker, N., C. L. Girard, R. Blouin, and P. Lacasse. 2020. Effects of feed restriction and supplementary folic acid and vitamin $\mathrm{B}_{12}$ on immune cell functions and blood cell populations in dairy cows. Animal 14:339-345. https://doi.org/10.1017/S1751731119002301.

Wang, S., S. Tian, M. Li, and Z. Li. 2018. Methionine attenuates the intensity of rheumatoid arthritis by downregulating NF- $\kappa B$ and iNOS expression in neonatal rats. 3 Biotech 8:303. https://doi .org/10.1007/s13205-018-1311-2.

Winkelstein, J. A. 1973. Opsonins: Their function, identity, and clinical significance. J. Pediatr. 82:747-753. https://doi.org/10.1016/ S0022-3476(73)80062-9.

Xue, G. P., and A. M. Snoswell. 1985a. Comparative studies on the methionine synthesis in sheep and rat tissues. Comp. Biochem. Physiol. B 80:489-494. https://doi.org/10.1016/0305-0491(85)90278-0.

Xue, G. P., and A. M. Snoswell. 1985b. Regulation of methyl group metabolism in lactating ewes. Biochem. Int. 11:381-385.

Zec, M., D. Roje, M. Matovinović, V. Antičević, L. Librenjak Škare, A. Jerončić, L. Puljak, S. Madunić, and Z. Meštrović. 2020. Vitamin $\mathrm{B}_{12}$ supplementation in addition to folic acid and iron improves hematological and biochemical markers in pregnancy: A randomized controlled trial. J. Med. Food 23:1054-1059. https://doi.org/ 10.1089/jmf.2019.0233.

Zenobi, M. G., R. Gardinal, J. E. Zuniga, A. L. G. Dias, C. D. Nelson, J. P. Driver, B. A. Barton, J. E. P. Santos, and C. R. Staples. 2018. Effects of supplementation with ruminally protected choline on performance of multiparous Holstein cows did not depend upon prepartum caloric intake. J. Dairy Sci. 101:1088-1110. https://doi .org/10.3168/jds.2017-13327.

Zhou, Z., O. Bulgari, M. Vailati-Riboni, E. Trevisi, M. A. Ballou, F. C. Cardoso, D. N. Luchini, and J. J. Loor. 2016a. Rumen-protected methionine compared with rumen-protected choline improves immunometabolic status in dairy cows during the peripartal period. J. Dairy Sci. 99:8956-8969. https://doi.org/10.3168/jds.2016 -10986 .

Zhou, Z., F. Ferdous, P. Montagner, D. N. Luchini, M. N. Corrêa, and J. J. Loor. 2018. Methionine and choline supply during the peripartal period alter polymorphonuclear leukocyte immune response and immunometabolic gene expression in Holstein cows. J. Dairy Sci. 101:10374-10382. https://doi.org/10.3168/jds.2018-14972.

Zhou, Z., M. Vailati-Riboni, D. N. Luchini, and J. J. Loor. 2016b. Methionine and choline supply during the periparturient period alter plasma amino acid and one-carbon metabolism profiles to various extents: Potential role in hepatic metabolism and antioxidant status. Nutrients 9. https://doi.org/10.3390/nu9010010.

\section{ORCIDS}

M. G. Lopes $\odot$ https://orcid.org/0000-0003-3955-445X V. Lopreiato (ํ) https://orcid.org/0000-0001-6965-7340

Y. Liang (ํ) https://orcid.org/0000-0003-1751-6823

D. N. Coleman @ https://orcid.org/0000-0002-8783-095X

M. T. Socha (1) https://orcid.org/0000-0002-0227-6591

M. A. Ballou ๑ https://orcid.org/0000-0002-9843-1196

E. Trevisi ๑ https://orcid.org/0000-0003-1644-1911

J. J. Loor @ https://orcid.org/0000-0003-1586-4365 